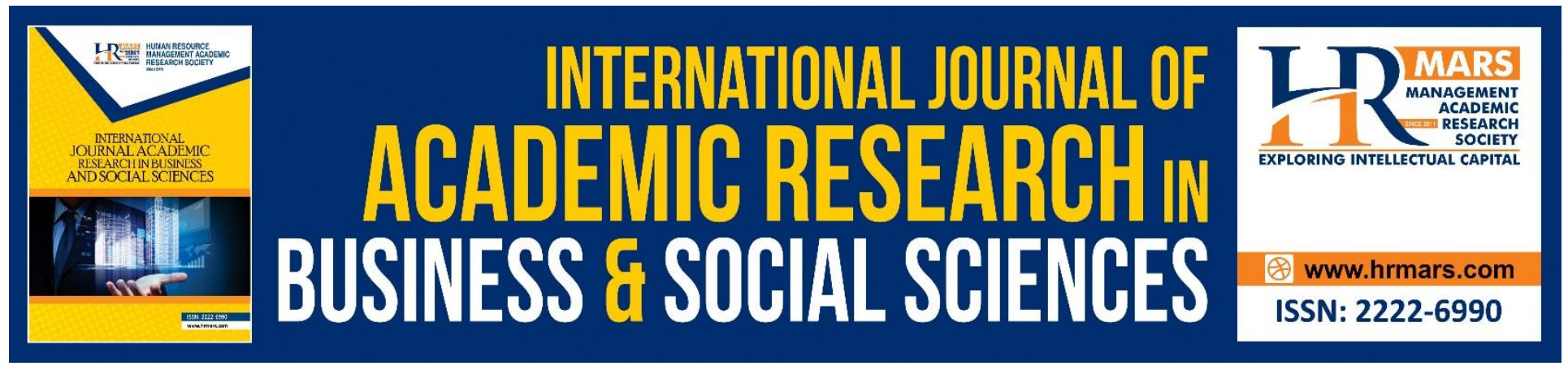

\title{
Effect of Internal Marketing on Employee Job Satisfaction in Commercial Banks in South East Nigeria
}

Chidubem Geoffrey Egbosi, Onyinyechi Rita Chijionwu, Tochukwu Henrietta Enidom, Michael O. Mojekeh

To Link this Article: http://dx.doi.org/10.6007/IJARBSS/v9-i4/5824

DOI: $10.6007 /$ IJARBSS/v9-i4/5824

Received: 22 Feb 2019, Revised: 12 March 2019, Accepted: 28 March 2019

Published Online: 13 April 2019

In-Text Citation: (Egbosi, Chijionwu, Enidom, \& Mojekeh, 2019)

To Cite this Article: Egbosi, C. G., Chijionwu, O. R., Enidom, T. H., \& Mojekeh, M. O. (2019). Effect of Internal Marketing on Employee Job Satisfaction in Commercial Banks in South East Nigeria. International Journal of Academic Research Business and Social Sciences, 9(4), 104-115.

Copyright: (C) 2019 The Author(s)

Published by Human Resource Management Academic Research Society (www.hrmars.com)

This article is published under the Creative Commons Attribution (CC BY 4.0) license. Anyone may reproduce, distribute, translate and create derivative works of this article (for both commercial and non-commercial purposes), subject to full attribution to the original publication and authors. The full terms of this license may be seen

at: http://creativecommons.org/licences/by/4.0/legalcode

Vol. 9, No. 4, 2019, Pg. 104 - 115

http://hrmars.com/index.php/pages/detail/IJARBSS

JOURNAL HOMEPAGE

Full Terms \& Conditions of access and use can be found at http://hrmars.com/index.php/pages/detail/publication-ethics 


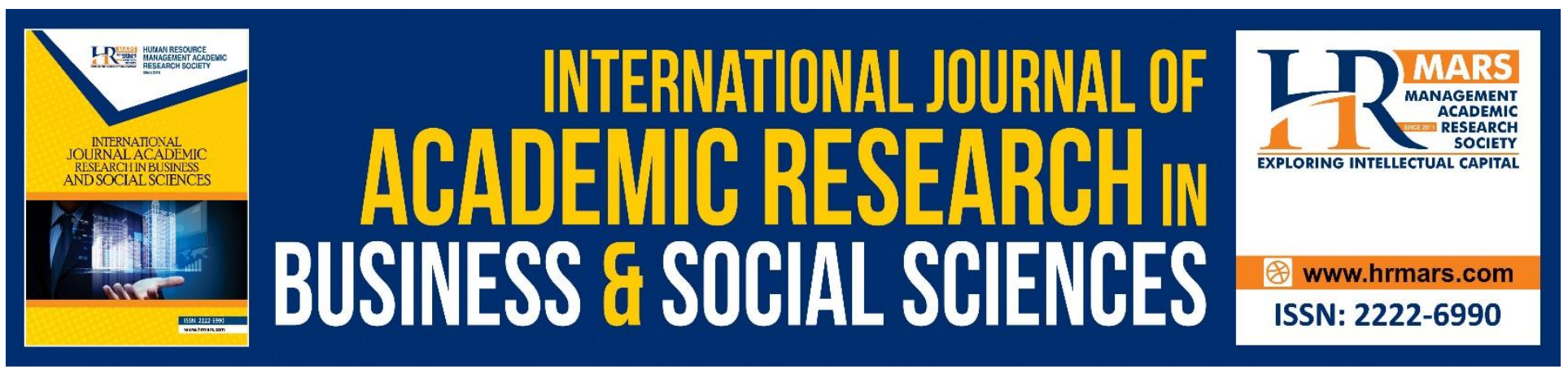

\title{
Effect of Internal Marketing on Employee Job Satisfaction in Commercial Banks in South East Nigeria
}

\author{
Chidubem Geoffrey Egbosi, Onyinyechi Rita Chijionwu, Tochukwu \\ Henrietta Enidom, Michael O. Ph.D. Mojekeh \\ Department of Marketing, \\ Chukwuemeka Odumegwu Ojukwu University, Igbariam Campus
}

\begin{abstract}
This work examined the effect of internal marketing on employee job satisfaction in selected commercial banks in South East Nigeria. Relevant conceptual, theoretical and empirical literatures were reviewed. Equity theory was employed as the theoretical framework. The study adopted survey research design. The population of the study constituted 13,990 customers of five selected commercial banks. The sample size for the study is 389. Employee training, internal communication, employee recognition and employee promotion were employed as the independent variable, while employee job satisfaction, was employed as the dependent variable. Data generated through questionnaire were analyzed using descriptive statistics, correlation analysis and multiple regression analysis. It was discovered that employee training has significant positive effect on employee job satisfaction, in commercial banks in South East Nigeria. The study also found that internal communication has a significant positive effect, on employee job satisfaction in commercial banks, in South East Nigeria. The study further found that employee recognition has a significant positive effect on employee job satisfaction, in commercial banks in South East Nigeria. Finally the study found that employee promotion has significant positive effect on employee satisfaction in commercial banks in South East Nigeria. The study concluded that internal marketing has significant positive effect on employee job satisfaction, in commercial banks in South East Nigeria. The study recommended that banks need to focus on internal marketing programs, to achieve and sustain a competitive position in the market through improved service quality.
\end{abstract}

Keywords: Internal marketing, Employee, Job Satisfaction, Commercial banks 


\section{Introduction}

Today, organizations operate in a dynamic, uncertain and challenging environment. Continuous changes and transformations in the socio-cultural conditions, as well as political upheavals, economic cycles, technological advances and changes in international relations all contribute to make the task of operating any organization successfully very daunting. Environmental dynamics and increasing competition lead organizations to become more competitive and to be sensitive to their customers satisfaction (Hassan \& Maedeh, 2013). This brought about internal marketing. The relevance of internal marketing to service providers rests in the increased emphasis on service quality in customer oriented corporations. Customers no longer simply purchase products; they co-produce in service organizations. The co-production occurs through the front-line employees and the customer at the time of transaction, therefore, the customer buying experience must be understood from both the organizational and customer perspective. This places greater emphasis on the process where each member must feel responsible for the outcome.

Internal marketing is a process that creates an environment where every member acts as both a client and customer in order to create responsibility (Wambugu, 2015). Huang (2003) measured that internal marketing is intended to employ, educate, and motivate the internal employee, and encourage them to recognize and acknowledge the concepts and importance of customer orientation, satisfaction, as well as support and assist the marketing department to provide excellent customer service. Johnson, Scheuing and Gaida (2006) suggested that internal marketing means creating an internal environment with customer orientation and service realization in the organization. Internal market includes company employees who have to be involved with the business and are part of a business. They are important for marketing, so that employees with high levels of satisfaction and those who have long-term relationships with companies and are familiar with it, because they have a very high degree of knowledge and experience, have necessary potential for customer satisfaction and building trust and relationships with customers respectively (Sin, Tse, Yau, Chow, Lee \& Lau, 2005). The main objective of internal marketing is to ensure employees' satisfaction and developing products and services in order to gain external customer satisfaction, and this process is from internal clients to external clients.

Today, service organizations focus their attention towards the attraction and retention of their internal customers (Ahmed, Rafiq \& Saad, 2003). Highly competitive business environment renovates the high quality employees as valuable asset of organizations and makes them differentiating factor and the organization's competitive advantage. Internal marketing advocates that competitive service industry can only achieve job satisfaction and sustainability by hiring, training and rewarding service employees that are willing and able to deliver quality service in customer-oriented ways. Internal marketing is based on the notion that employees of an organisation should be handled as internal customers and should be presented as internal products that satisfy the needs and desires of external customers (Nebo \& Okechukwu, 2017).

The overall implication of internal marketing is that, when an employee is satisfied by his organization, he is most likely to deliver quality service to the external customers (Ogunnaike, Oyeniyi \& Adeniji, 2012). The goal of internal marketing actually is to make employees as important as the external customers by treating them as internal customers. Lings and Greenley (2005) advocate that the goal of internal marketing lies in motivating the employees and encouraging them to offer 
superior services to customers which will improve the customers' satisfaction of the company services.

The ability to increase performance involves employee job satisfaction, and it was described as an outcome of internal marketing, (Ahmed \& Rafiq, 2003). The researchers hypothesize that if internal marketing is effectively implemented, the employee becomes satisfied. Against this backdrop, the banking industry has realized the importance of internalizing the marketing skills by all staff in banks to facilitate external marketing to improve customer satisfaction. Based on the foregoing, this study examined the effect of internal marketing on employee job satisfaction in commercial banks in South East Nigeria. The service industry poses crucial challenge for managers to handle due to involvement of human element in delivering the optimal services. The proliferation of technology and globalization of businesses have created a sturdy competition among business firms and this competition is significant, not only in manufacturing industries, but also in service industries like banks. Often, banks in Nigeria are confronted with the problem of effective service delivery.

Customers' needs in some of these banks appear to be taken for granted by the so called frontline service employees even in the face of tight competition in the industry. Some of the employees appear unfriendly, impolite, undependable, untrustworthy, fraudulent, unsympathetic, repulsive, uncommitted to their jobs and sometimes too busy to respond promptly to customers' queries. The challenge for most bank managers in Nigeria is how to improve the behaviours of the service employees in order to serve customers' better. Also, the banking industry has already been depicted as exhibiting little market orientation and fulfilling service with little regard to customer needs as well as including branches dissimilar in efficiency, long lines, limited time for customer servicing, transaction errors, excessive bureaucracy, security and network failures which are the most frequent problems with using banking services (Daniel, 2003). As a result, customer satisfaction levels are at all time low, dragging the bank's image, credibility and staff morale down (Schltze, 2003).

Previous studies on internal marketing and customer satisfaction revealed mixed empirical findings. These mixed empirical findings show that the relationship between internal marketing and customer satisfaction is not yet resolved. Similarly, majority of the studies reviewed were done in environment outside Nigeria showing a knowledge gap within the Nigerian context especially in relation to customer satisfaction. In the light of the above identified gaps, this study examined the effect of internal marketing on employee job satisfaction on commercial banks in South East Nigeria using a more robust statistical tool and industry wide data. The broad objective of the study is to examine the effect of internal marketing on employee job satisfaction. The specific objectives are to: determine the effect of employee training; internal communication; employee recognition and employee promotion on employee job satisfaction.

\section{Hypotheses}

$\mathrm{Ho}_{1}$ : Employee training has no effect on employee job satisfaction in commercial banks in South East Nigeria.

$\mathrm{Ho}_{2}$ : Internal communication has no effect on employee job satisfaction in commercial banks in South East Nigeria.

$\mathrm{Ho}_{3}$ : Employee recognition has no effect on employee job satisfaction in commercial banks in South East Nigeria. 
INTERNATIONAL JOURNAL OF ACADEMIC RESEARCH IN BUSINESS AND SOCIAL SCIENCES

Vol. 9, No. 4, April, 2019, E-ISSN: 2222-6990 ㄷ 2019 HRMARS

$\mathrm{Ho}_{4}$ : Employee promotion has no effect on employee job satisfaction in commercial banks in South East Nigeria.

\section{Review of Related Literature}

\section{Internal Marketing}

The concept of internal marketing emerged from the development of business structures and services marketing (Varey \& Lewis, 2000). Internal Marketing (IM) is a specialized marketing communication approach to add value to employee as an internal customer towards delighting external customers that result to overall business performance. In particular, internal marketing has been perceived as a means of creating a sustainable competitive advantage in the market place through provision of high service quality (Cronin \& Taylor, 2012). Internal marketing has been described as a process of attracting, developing, motivating and retaining qualified employees through job-products that satisfy their needs (Gafar, Inda \& Ifu, 2016). Basically, it refers to the philosophy of treating employees as customers and the strategy of shaping jobs to fit human needs (Ruizalba, Bermúdez-González, Rodríguez-Molina \& Blanca, 2014). Meanwhile, Alajoutsijärvi, Mainela, Salminen and Ulkuniemi (2012) described IM as a fruitful means of integrating various business functions as production, personnel and technological development, so that marketing really can become an integrative function in the service company.

\section{Job Satisfaction}

Job satisfaction in general refers to the emotions the employee feels about his job, and how he reacts to them (Tadeka, 2005). Job satisfaction is a broadly studied concept in numerous occupational fields. Porter and Lawler's (1968) definition of job satisfaction includes both internal and external satisfaction. From the above definition internal satisfaction refers to the causes that create job satisfaction, and are closely related to the job itself. In other meanings, it is the level of satisfaction achieved through the job itself, through facets such as sense of achievement, growth, self-esteem, independence, and sense of control (Shimizu et al, 2005). On the other hand, external satisfaction, is indirectly related to the job itself, and includes such facets as good working environment, welfare, high salary, promotion, etc.

\section{Theoretical Framework}

This research work is anchored on equity theory. Equity theory was developed by Stacey Adams founded in 1963 to explain motivation in an organization through comparison of various individuals within the organization and others in other organizations. The theory looks into the issues of fairness from the comparison of different employees. This theory is anchored on three principles of fairness to perception applied to organisation settings. These principles include distributive justice or the perception of equality of an individual outcome. This theory is related to internal marketing and employee job satisfaction because when there is equity in the organization; individuals are likely to feel proud of their organization making it easier to perpetuate internal marketing. This is done by the comparison of the ratio of outcome to input of one employee to the output to input of the other in 
the same or different organizations. The differences in results of the comparison depict the extent of job satisfaction, which is primarily through the implementation of internal marketing.

\section{Empirical Review}

Empirically, Wambugu (2015) found that internal marketing has a positive impact on customer satisfaction. Aburoub, Hersh and Aladwan (2011) found that internal marketing has significant relationship with customer satisfaction. Sara and Leila (2015) found that internal marketing affects customer satisfaction through customer orientation significantly. Also, Bavarsad and Leila (2015)? found internal marketing affects customer satisfaction through customer orientation significantly. Similarly, Ms. Javeria and Rashid (2014) found that internal marketing practice has positive influence on employee job satisfaction. Waddah and Nooraini (2016) found that internal marketing has a significant relationship with job satisfaction. Baran and Arabelen (2017) found that internal marketing (development, vision and communication, and reward system) has a positive effect on job satisfaction. Also, Ahmad and Al-Borie (2012) found that internal marketing (selection and appointment, training and development, organizational support, incentives and motivation, and retention policy) had a positive effect on job satisfaction. Khaled (2015) found that internal marketing (training and development, organizational support, incentives and motivation, and retention policy) had a positive effect on the National bank of Egypt employees' job satisfaction. On the contrary, Abdoreza, Mahdi, Mohammad and Mohadesh (2015) found no significant relationship between internal marketing and job satisfaction.

Previous studies on internal marketing and employee job satisfaction revealed mixed empirical findings. This mixed empirical findings shows that the relationship between internal marketing and employee job satisfaction is not yet resolved. Similarly, majority of the studies reviewed were done in environment outside Nigeria showing a knowledge gap within the Nigerian context especially in relation to employee job satisfaction. In the light of the above identified gaps, this study examined the effect of internal marketing on employee job satisfaction using a more robust statistical tool and industry wide data.

\section{Methodology}

The study adopted survey research method. This study was carried out in South East Nigeria. SouthEast is one of the six geo-political zones in Nigeria consisting of Abia State, Anambra State, Ebonyi State, Enugu State and Imo State. Employees of 5 selected commercial banks where used for the study. The banks include First Bank of Nigeria Plc, Zenith Bank of Nigeria Plc, Fidelity Bank Plc, Union Bank of Nigeria Plc and Key Stone Bank. Employees of these commercial banks were used for the study. The population of the study is 13,990 employees. The statistical formula devised by Taro Yamane was used to arrive at sample size of 389. Multiple regression analysis was employed in analyzing data.

\section{Analysis of Data and Discussion of Findings}


INTERNATIONAL JOURNAL OF ACADEMIC RESEARCH IN BUSINESS AND SOCIAL SCIENCES

Vol. 9, No. 4, April, 2019, E-ISSN: 2222-6990 ㄷ 2019 HRMARS

Multiple regression analysis was employed to determine the effect of the independent variables on the dependent variable. The essence is to ascertain the effect of internal marketing on employee job satisfaction. The results are presented in tables 1 and 2 .

Table 1: Summary of Regression Result

\begin{tabular}{llrrrr}
\hline Model & R & R Square & $\begin{array}{c}\text { Adjusted R } \\
\text { Square }\end{array}$ & $\begin{array}{l}\text { Std. Error of } \\
\text { the Estimate }\end{array}$ & $\begin{array}{l}\text { Durbin- } \\
\text { Watson }\end{array}$ \\
\hline 1 & $.174^{\mathrm{a}}$ & .530 & .617 & 3.197 & 2.745 \\
\hline
\end{tabular}

a. Predictors: (Constant), Employee Training, Internal Communication, Employee Promotion, Employee Recognition

b. Dependent Variable: Employee Job Satisfaction

Source: SPSS Ver. 21

Table 1 above indicates that $\mathrm{R}^{2}$ which measures the strength of the effect of independent variable on the dependent variable have the value of 0.530 . This implies that $53.0 \%$ of the variation in employee job satisfaction is explained by variations in internal marketing variables (employee training, internal communication, employee promotion and employee recognition). This was supported by adjusted $\mathrm{R}^{2}$ of $61.7 \%$. The Durbin-Watson statistics was employed to check for autocorrelation in the model. Durbin-Watson statistics of 2.742 showed that the variables in the model are not auto-correlated and are therefore, reliable for predications.

Table 2: ANOVA Result

\begin{tabular}{|c|c|c|c|c|c|c|}
\hline \multicolumn{2}{|c|}{ Model } & \multirow{2}{*}{$\begin{array}{l}\begin{array}{l}\text { Sum of } \\
\text { Squares }\end{array} \\
112.562\end{array}$} & Df & Mean Square & \multirow{2}{*}{$\frac{\mathbf{F}}{72.203}$} & \multirow{2}{*}{$\frac{\text { Sig. }}{.004^{a}}$} \\
\hline 1 & Regression & & 5 & 22.512 & & \\
\hline & Residual & 3587.511 & 351 & 10.221 & & \\
\hline & Total & 3700.073 & 356 & & & \\
\hline
\end{tabular}

a. Predictors: (Constant), Employee Training, Internal Communication, Employee Promotion, Employee Recognition

b. Dependent Variable: Employee Job Satisfaction

Source: SPSS Ver. 21 
The F-test was applied to check the overall significance of the model. The F-statistic was instrumental in verifying the overall significance of an estimated model. The f-statistics value of 72.203 in table 2 above with probability value of 0.004 showed that the independent variables has significant effect on dependent variable. This showed that employee training, internal communication, employee promotion and employee recognition can collectively explain the variations in employee job satisfaction. This showed that internal marketing has a significant positive effect on employee job satisfaction.

\section{Test of Hypotheses}

Here, the four hypotheses formulated earlier in this study were tested using the t-statistics and probability from the coefficient result of the multiple regression analysis. The results are presented the table 3 below.

Table 3 Coefficients of the Regression Result

\begin{tabular}{|c|c|c|c|c|c|c|}
\hline & & \multicolumn{2}{|c|}{$\begin{array}{l}\text { Unstandardized } \\
\text { Coefficients }\end{array}$} & \multirow{2}{*}{$\begin{array}{c}\begin{array}{c}\text { Standardized } \\
\text { Coefficients }\end{array} \\
\text { Beta }\end{array}$} & \multirow[b]{2}{*}{$t$} & \multirow[b]{2}{*}{ Sig. } \\
\hline \multicolumn{2}{|c|}{ Model } & B & Std. Error & & & \\
\hline \multirow[t]{5}{*}{1} & (Constant) & 22.159 & 1.757 & & 12.612 & .000 \\
\hline & Employee Training & 1.040 & .040 & .054 & 2.003 & .007 \\
\hline & $\begin{array}{l}\text { Internal } \\
\text { Communication }\end{array}$ & .056 & .042 & .071 & 2.340 & .001 \\
\hline & $\begin{array}{l}\text { Employee } \\
\text { Recognition }\end{array}$ & 1.108 & .042 & .140 & 3.580 & .000 \\
\hline & $\begin{array}{l}\text { Employee } \\
\text { Promotion }\end{array}$ & .028 & .041 & .037 & 2.693 & .009 \\
\hline
\end{tabular}

a. Dependent Variable: Employee Job Satisfaction

Source: SPSS Version 21.0

\section{Test of Hypothesis One}

$\mathrm{Ho}_{1}$ : Employee training has no significant effect on employee job satisfaction in commercial banks in South East Nigeria.

Table 3 above indicated that employee training recorded a t-statistics value of 2.340 with a probability value of 0.001 which is statistically significant at $5 \%$ level of significance. Therefore, the null hypothesis is rejected while the alternative hypothesis is accepted. This implies that employee training has significant positive effect on employee job satisfaction in commercial banks in South East Nigeria.

\section{Test of Hypothesis Two}

$\mathrm{Ho}_{2}$ : Internal communication has no significant effect on employee job satisfaction in commercial banks in South East Nigeria. 
Internal communication recorded a t-statistics value of 2.003 with an alpha value of 0.007 . Therefore, the null hypothesis is rejected while the alternative hypothesis is accepted. This implies that internal communication has significant positive effect on employee job satisfaction in commercial banks in South East Nigeria.

\section{Test of Hypothesis Three}

$\mathrm{Ho}_{3}$ : Employee recognition has no significant effect on employee job satisfaction in commercial banks in South East Nigeria.

Employee recognition recorded a t-statistics value of 3.580 with a probability value of 0.000 which is statistically significant at $5 \%$ level. Therefore, the null hypothesis is rejected. It is therefore concluded that employee recognition has significant positive effect on employee job satisfaction in commercial banks in South East Nigeria.

\section{Test of Hypothesis Four}

$\mathrm{Ho}_{4}$ : Employee promotion has no significant effect on employee job satisfaction in commercial banks in South East Nigeria.

Employee promotion has a t-statistics value of 2.693 with a probability value of 0.009 which is statistically significant at $5 \%$ level. Therefore, the null hypothesis is rejected. It is therefore concluded employee promotion has significant positive effect on employee job satisfaction in commercial banks in South East Nigeria.

\section{Summary of Findings}

This work examined the effect of internal marketing on employee job satisfaction. Employees of five commercial banks in South East Nigeria were sampled for the study. Data generated were analyzed using descriptive statistics and multiple regression analysis. The study found that employee training has significant effect on employee job satisfaction in commercial banks in South East Nigeria. This tallied with the findings of Ahmad and Al-Borie (2012) who found that internal marketing (selection and appointment, training and development, organizational support, incentives and motivation, and retention policy) had a positive effect on job satisfaction. This further agreed with the findings of Ahmad et al (2012) and Khaled (2015) that training and development has a significant impact on job satisfaction.

The study also found that internal communication has significant effect on employee job satisfaction in commercial banks in South East Nigeria. This agreed with the findings of Wambugu (2015) that communication has positive impact on customer satisfaction. This also tallied with the findings of Waddah et al (2016) that internal communications has significant relationship with job satisfaction. Furthermore, employee recognition was found to have significant effect on employee job satisfaction in commercial banks in South East Nigeria. This also agreed with the findings of Aburoub et al (2011) that motivation system and rewards have significant relationship with customer satisfaction. This agreed with the findings of Waddah et al (2016) that rewards have a significant relationship with job satisfaction. This further tallied with the findings of Ahmad et al (2012) and Khaled (2015) that incentives and motivation has a significant impact on job satisfaction. 
Finally, employee promotion was found have significant effect on employee job satisfaction in commercial banks in South East Nigeria. This tally with the findings of Wambugu (2015) rewards received and promotion have positive impact on customer satisfaction.

\section{Conclusion}

Internal marketing strategies and activities are becoming major research phenomena in business. Many marketing scholars argue for the strong effect of the powerful internal marketing on both internal and external customers, therefore, this work examined the effect of internal marketing on employee job satisfaction in selected commercial banks. Data generated were analyzed using multiple regression analysis. It was discovered that employee training has significant positive effect on employee job satisfaction in commercial banks in South East Nigeria. The study also found that internal communication has significant positive effect on employee job satisfaction in commercial banks in South East Nigeria. The study further found that employee recognition has significant positive effect on employee job satisfaction in commercial banks in South East Nigeria. Finally the study found that employee promotion has significant positive effect on employee job satisfaction in commercial banks in South East Nigeria.

The philosophy of internal marketing is that employees of an organization constitute its internal market, which has customers and suppliers and as a result, a chain of value if formed inside the organization which must be intended to supply the needs of both the internal and external customers. Reaching customers and winning their satisfaction is achieved through reaching level of quality required in all marketing relations between organization and customers. When the internal customers of an organization are satisfied they will perform better and maintain better interaction with the customers. As a result, the customers will get more satisfied, which will bring about their faithfulness in the long run and ultimately a competitive advantage will be obtained from the internal customers. Based on the findings of this study therefore, the study concludes that internal marketing has a significant positive effect on employee job satisfaction in commercial banks in the South East Nigeria.

\section{Recommendations}

Based on the findings and conclusion of this study, the following were recommended:

1. Managers need to focus on internal marketing programs to achieve and sustain a competitive position in the market through improved service quality. Managers should emphasize on satisfying the needs and wants of their employees to attract and retain customers through improved customer satisfaction.

2. Internal marketing should evolve around frontline employees and the process must start with senior leadership and a proper physical environment. Also frontline employees should be motivated through strategic awards, other incentives, and individual empowerment to make decisions without the assistance of upper management.

3. Managers and decision makers in banks have to focus on developing the different skills in the employees and encourage them to be creative and discover their abilities by assigning them in training courses that suit employee's skills or their interest. 
4. Managers have to involve the empowerment practice, because it is proven that when employees are participants in the decision making process, they provide a much better service to customers. The managers have the choice to encourage the employees in making decisions in cases where the decision made is simple and a routine decision not a major one, but this small participation can have a great satisfactory results from the employees toward their jobs and eventually the satisfaction of the customers.

5. Managers in banks also have to communicate with their subordinates effectively in order to make them satisfied with their jobs. So, in order to achieve employees' satisfaction managers have to organize weekly meetings with the employees to hear their opinions and feedbacks on the job and should take what they said into consideration.

\section{References}

Abdoreza, A., Mahdi, S. A., Mohammad, J. A., \& Mohadesh, S. (2015). The relationship between internal marketing and customer satisfaction in private men's swimming pool of Tehran. International Journal of Biology, Pharmacy and Allied Sciences, 4(7), 933 - 944.

Aburoub, A. S., Hersh, A. M., \& Aladwan, K. (2011). Relationship between internal marketing and service quality with customers' satisfaction. International Journal of Marketing Studies, 3(2), $107-118$.

Ahmad, A. M. K., \& Al-Borie, H. M. (2012). Impact of internal marketing on job satisfaction and organizational commitment: A study of teaching hospitals in Saudi Arabia. Business and Management Research, 1(3), $82-94$.

Ahmed, P. K, \& Rafiq, M. (2003). Internal marketing issues and challenges. European Journal of Marketing, 37(9),1177-1186.

Ahmed, P.K., Rafiq, M., \& Saad, N.M. (2003). Internal marketing and the mediating role of organizational competencies. European Journal of Marketing, 37(9), 1221-41.

Alajoutsijärvi, K., Mainela, T., Salminen, R., \& Ulkuniemi, P. (2012). Perceived customer involvement and organizational design in project business. Scandinavian Journal of Management, 28(1), 77-89.

Baran, E., \& Arabelen, G. (2017). The effects of internal marketing on ship agents' job satisfaction: A quantitative research. Araştırma Makalesi (Research Article), 9(1), 25 - 54.

Bavarsad, S. P., \& Leila, A. (2015)]? Investigating the impact of internal marketing on customer orientation (Case Study: Insurance Industry of Abadan City). European Online Journal of Natural and Social Sciences, 4(3), $546-552$.

Cronin, J. J. Jr, \& Taylor, S. A. (2012). Measurement service quality a re-examination and extension. Journal of Marketing, 7, 55-68.

Daniels, S. (2003). Employee training: A strategic approach to better return on investment. Journal of Business Strategy, 24(4), 39-42.

Gafar, O. Y., Inda, S., \& Ifu, A. (2016). Internal marketing practices and customer orientation of employees in Nigeria banking sector. International Review of Management and Marketing, $6(4), 217-223$. 
INTERNATIONAL JOURNAL OF ACADEMIC RESEARCH IN BUSINESS AND SOCIAL SCIENCES

Vol. 9, No. 4, April, 2019, E-ISSN: 2222-6990 @ 2019 HRMARS

Hassan, G., \& Maedeh, M. (2013). The impact of direct and indirect of internal marketing on service quality and mediating role of OCB Case: Iran Insurance Company. International Journal of Academic Research in Business and Social Sciences, 3(11) $116-127$.

Huang, J. Y. (2003). World studied in marketing, second edition. Taipei: Common Wealth.

Johnson, E. M., Scheuing, E. E., \& Gaida, A. K. (2006). Profitable service marketing. Homewood, IL: Dow-Jones Irwin.

Khaled, A. G. (2015). The role of internal marketing in job satisfaction of employees in the National Bank of Egypt Journal of. College of Management and Technology Arab Academy for Science, Technology and Maritime Transport.

Lings, I. N., \& Greenley, G. E. (2009). The impact of internal and external market orientations on firm performance. Journal of Strategic Marketing, 17(1), 41- 53.

Ms.Javeria S., \& Rashid, A. S. (2014). Impact of internal marketing on employee job satisfaction: An investigation of Higher Education Institutes of Pakistan. Journal of Marketing Management, 2(2) $239-253$.

Nebo, G. N., \& Okechukwu, E. U. (2017). Effects of internal marketing on customer orientation behaviour of selected hotels' employees in Nigeria. European Scientific Journal, 13(16), 212 232.

Ogunnaike, O. O., Oyeniyi, O., \& Adeniji, A. A. (2012). Internal marketing practices and job satisfaction: evidence from a Nigerian university setting. BRAND. Broad Research in Accounting, Negotiation, and Distribution. 3 (3), pp. 18-30.

Ruizalba, J.L., Bermúdez-González, G., Rodríguez-Molina, M.A., \& Blanca, M.J. (2014), Internal market orientation: An empirical research in hotel sector. International Journal of Hospitality Management, 38, 11-19.

Sin, L. Y. M., Tse, A. C. B., Yau, O. H. M., Chow, R. P. M., Lee, J. S. Y., \& Lau, L. B. Y. (2005). Relationship marketing orientation: scale development and cross-cultural validation. Journal of Business Research, 58(2), 185-194.

Tadeka, F., Ibaraki, N., Yokoyama, E., Miyake, T., \& Ohida, T. (2005). The relationship of job type to burnout in social workers at social welfare offices. Journal Occupational Health, 47(2) 119125.

Varey, J. R., \& Lewis, R. B. C. (2000). A broadened conception of internal Marketing. European Journal of Marketing, 33(9-10), 926-944.

Waddah, I., \& Nooraini, M. S. (2016). Impact of internal marketing on job satisfaction among bank employees in Yemen. 3rd International Conference on Business and Economics, 21 - 23 September.

Wambugu, L. (2015). Impact of internal marketing on service quality and customers satisfaction: A case study of Equity Bank, Kengeleni Branch. Research Journal of Finance and Accounting, 6(19), $57-67$. 